\title{
Tillage and Post-Emergence Herbicides Effect on Weed Growth and Productivity of Wheat (Triticum aestivum L.)
}

\author{
Pramod Kumar Singh $^{1 *}$, Pradeep Prasad ${ }^{1}$, Manita Kumari ${ }^{3}$ and Rajiv Nayan ${ }^{2}$ \\ ${ }^{1}$ Department of Agronomy, ${ }^{2}$ Department of Extension, SHAITS, Allahabad (U.P.), India \\ ${ }^{3}$ Department of Plant protection, T.D. College, Jaunpur (U.P), India \\ *Corresponding author
}

\begin{abstract}
A B S T R A C T
The conventional use of the same post-emergence herbicides repeatedly may result in poor management of the early weed flush in wheat under zero-tilled (ZT) condition. This may hasten development of herbicide resistant weeds as well. In this study, a possible weed management has been envisaged in ZT and conventional till (CT) wheat during 2013-14 and 2014-15 using tillage and weed control treatments. It was observed that ZT caused a

\section{Keywords}

Post-emergence herbicides, Tillage, Weed control, Wheat.

Article Info

Accepted:

19 June 2017

Available Online:

10 July 2017 considerable reduction in the population of narrow-leaved, broad-leaved and total weeds compared to CT. Among the herbicides, sulfosulfuron at $25 \mathrm{~g} \mathrm{ha}^{-1}+$ metsulfuron methyl at $4 \mathrm{~g} \mathrm{ha}^{-1}$ and clodinafop at $60 \mathrm{~g} \mathrm{ha}^{-1}+$ carfentrazone ethyl at $20 \mathrm{~g} \mathrm{ha}^{-1}$ were promising and it has an edge over other for reduction in weed population and dry weight. The weed control efficiency (WCE) was also higher in ZT treatments than the conventional treatments in both the years. Application of sulfosulfuron at $25 \mathrm{~g} \mathrm{ha}^{-1}+$ metsulfuron methyl at $4 \mathrm{~g} \mathrm{ha}^{-1}$ and clodinafop at $60 \mathrm{~g} \mathrm{ha}^{-1}+$ carfentrazone ethyl at $20 \mathrm{~g} \mathrm{ha}^{-1}$ as post-emergence recorded higher WCE. Similarly, ZT with sulfosulfuron at $25 \mathrm{~g} \mathrm{ha}^{-1}+$ metsulfuron methyl at $4 \mathrm{~g} \mathrm{ha}^{-1}$ and clodinafop at $60 \mathrm{~g} \mathrm{ha}^{-1}+$ carfentrazone ethyl at $20 \mathrm{~g} \mathrm{ha}^{-1}$ as post-emergence recorded significantly higher wheat crop growth parameter viz. plant height, number of tillers, and dry matter accumulation in both the years. The treatments were comparable with weed free check and recorded higher wheat crop growth. The highest grain and straw yield of wheat was recorded in ZT and it was significantly higher than CT in both the years. Weeds were found to reduce the grain yield significantly. The highest grain yield was recorded in weed free check followed by sulfosulfuron at $25 \mathrm{~g} \mathrm{ha}^{-1}+$ metsulfuron methyl at $4 \mathrm{~g} \mathrm{ha}^{-1}$ and clodinafop at $60 \mathrm{~g} \mathrm{ha}^{-1}+$ carfentrazone ethyl at $20 \mathrm{~g} \mathrm{ha}^{-1}$. The B: C ratio was higher with, sulfosulfuron at $25 \mathrm{~g} \mathrm{ha}^{-1}+$ metsulfuron methyl at $4 \mathrm{~g} \mathrm{ha}^{-1}$ under ZT which was significantly higher than UWC.
\end{abstract}

\section{Introduction}

Wheat is one of the most important food-grain of India next to rice and is the staple food of millions of Indians, particularly in the Northern and North-western parts of the country. Due to the Green revolution, the production level of wheat in India had a quantum jump from 6.46 million tonnes from an area of 9.75 million hectares in 1950-51 to more than 93 million tonnes from an area of about 30 million hectares during 2011-12. Currently, India is the second largest producer of wheat in the world after China with about $12 \%$ share in total world wheat production but due to a high rate of population growth the present production of 93 million tonnes seems to be insufficient and strategies to increase 
production are needed. The major constraint in wheat under rice-wheat cropping system is low wheat production because of low farm mechanization and delayed sowing.

The soil is heavy after rice harvesting having high moisture content which hampers normal ploughing for wheat sowing even after harvest of rice in late December. Thus, there is a delay of 15 to 25 days in sowing of wheat and here the crop is sown till mid-January. This delay cause's reduction in wheat crop yield severely as $15^{\text {th }}$ November to $10^{\text {th }}$ December is the recommended sowing time of wheat in this region (Singh et al., 2005a). The reduction in wheat yield has been reported up to 55\% (Singh et al., 2002). The new zero tillage (ZT) technology in wheat has been an important solution for the problem as it has proven its worth in the rice-wheat cropping system (Yadav et al., 2009).

Although ZT is a successful technology, weeds are great menace in the initial year of adoptions. Weeds, the unwanted plants, compete with crops for nutrition, water, sunlight, space and air are fast in growth and produce large number of seeds which remain dormant in soil and become live in favourable climate. Thus, weeds cause significant reduction in all crops yield and so is the case with wheat. Infestation of Phalaris minor, a weed of wheat, alone has been found to cause $40 \%$ reduction in yield (Singh et al., 2005b). In South Bihar, before sowing of wheat, presence of some broad leaf weeds like Desmodium trifolium and narrow leaf weeds are common (Singh and Singh, 2005). With regard to no till system, which are characterized by depositing seeds on top soil (Morris et al., 2010), it is necessary to follow an appropriate procedure to avoid high weed densities and prevent un acceptable problems. For the adoption of conservation agriculture system and their wide spread, weed flora and its dynamics must be understood carefully for their control (Brainnard et al., 2013). Weeds in wheat are generally controlled by manual and cultural methods but these are time taking methods and often not done in proper time. Therefore, nowadays herbicide use for controlling weeds is becoming popular in wheat as well as other food crops. They are easy to apply and other inexpensive, compared to other weed control methods. Herbicide use has increased in both conventional tillage (CT) and ZT systems because it provides effective and economical weed control and saves labour which has become more scarce and expensive (Rao et al., 2007). Continuous use of single herbicide with a recommended dose may hasten the development of resistance weed flora. Therefore, evaluation of new generation herbicide and herbicides mixture for effective weed control in wheat under conventional and $\mathrm{ZT}$ is need of the hour. Keeping all the facts into consideration, the present investigation was under for evaluating new generation herbicides in wheat under different tillage systems.

\section{Materials and Methods}

\section{The study site}

The experiment was conducted for two years at research station of the Krishi Vigyan Kendra, Khadigram, Jamui (Bihar) $\left(24^{0} 5 \mathrm{~N}\right.$ latitude, $86^{\circ}$ 18. E longitude and $79 \mathrm{~m}$ above sea level) during 2013-14 and 2014-15. The average rainfall is $1110 \mathrm{~mm}$ and $80 \%$ of rainfall is received during July to September. Soil was sandy loam, $\mathrm{pH}$ 6.7, organic C $(0.45 \%)$, low in available nitrogen $(250.6 \mathrm{~kg}$ $\left.\mathrm{ha}^{-1}\right)$, high in $\mathrm{P}\left(31.2 \mathrm{~kg} \mathrm{ha}^{-1}\right)$ and medium $\mathrm{K}$ $\left(176 \mathrm{~kg} \mathrm{ha}^{-1}\right)$.

\section{The study method}

The experiment was conducted in factorial randomized block design in each year with 
three replications having two tillage level and thirteen herbicidal doses. The experiment was under rice-wheat cropping system. Conventional tillage plots were ploughed by a tractor-drawn disc plough followed by planking and ZT plots were left undisturbed. The weed-free check, the plots were maintained free of weeds through manual weeding as and when required. A pre-sowing irrigation was given to entire field to facilitate smooth germination of wheat. Wheat 'PBW 502 " was sown with a spacing of $20 \mathrm{~cm}$ between rows with a $125 \mathrm{~kg} \mathrm{ha}^{-1}$ seed rate. A dose of $10 \mathrm{~kg} \mathrm{~N}, 60 \mathrm{~kg} \mathrm{P}_{2} \mathrm{O}_{5}$ and $40 \mathrm{~kg} \mathrm{~K} 2 \mathrm{O}$ $\mathrm{ha}^{-1}$ was applied to wheat. Half dose of nitrogen was applied as basal and remaining half of nitrogen was applied in two equal split doses, one at crown root initiation stage that occurs around 21 days after planting and coincides with first irrigation and another at tillering stage (65 DAS) of wheat crop. Nitrogen, $\mathrm{P}$ and $\mathrm{K}$ were applied in the forms of urea, single superphosphate and muriate of potash, respectively. Required quantities of all herbicides were applied with 4001 water ha $^{-1}$ by knapsack sprayer with a flat fan nozzle at 25 DAS. An area of $0.25 \mathrm{~m}^{2}$ was selected at 60 DAS randomly at two spots by throwing a quadrat of $0.5 \mathrm{~m} \times 0.5 \mathrm{~m}$, weed species were counted from that area and density was expressed in number $\mathrm{m}^{-2}$. The collected weeds were first sun-dried and then kept in an electric oven at $70^{\circ} \mathrm{C}$ till the weight became constant, and dry weight was expressed as $\mathrm{g}$ $\mathrm{m}^{-2}$.

Weed control efficiency (WCE) was calculated at 60 DAS using the following formula and expressed in per cent:

$$
\text { WCE }(\%)=\frac{\text { Weed population in unweeded control plot }- \text { Weed population in treated plot }}{\text { Weed population in weedy plot }} \times 100
$$

In order to study the influence of different treatments on dry matter production, five plant samples from each plot were selected randomly at $60 \mathrm{DAS}$, air dried and then kept in hot air oven at $70^{\circ} \mathrm{C}$ for 72 hours and their dry weight recorded. The number of tillers was recorded randomly from five hills in each plot at 60 DAS. Average value was expressed in terms of tillers per meter row length. Wheat was harvested manually, but was threshed by a power-operated thresher. The cost of cultivation under various treatments was estimated on the basis of prevailing rates for inputs. The input costs of all the items like tillage operation, costs of seed, herbicide treatment application, chemical fertilizers, and the hiring charges of human labour and machines for land preparation, irrigation, fertilization, harvesting, and threshing. The benefit: cost ratios (B: C) were calculated for each treatments applied in the system as the ratios of net returns to cost of cultivation. The data recorded during the course of investigation was subjected to statistical analysis by "Analysis of variance technique" (Gomez and Gomez, 1984). The significant differences between the means were tested against the critical difference at 5\% probability level.

\section{Results and Discussion}

The weed species in the experimental site comprised of: Anagallis arvensis L., Melilotus indica L., Chenopodium album L., Convolvulus arvensis L., Melilotus alba L., Vicia sativa L. and Spergulla arvensis L. among broad-leaved, Phalaris minor Retz., Avena ludoviciana among grasses, and, Cyperus rotundus among sedge. At 60 DAS in both years, the significantly lowest weeds density was in ZT than CT (Table 1). Weed control treatments were found to reduce the weeds density than weedy check in both the 
years. Among the herbicidal treatments sulfosulfuron at $25 \mathrm{~g} \mathrm{ha}^{-1}+$ metsulfuron methyl at $4 \mathrm{~g} \mathrm{ha}^{-1}$ and clodinafop at $60 \mathrm{~g} \mathrm{ha}^{-1}$ + carfentrazone ethyl at $20 \mathrm{~g} \mathrm{ha}^{-1}$ were at par for total weeds density in both the years, but they were superior to remaining weed control practices. The significantly lower weeds dry weight was also obtained in ZT than CT. Application of sulfosulfuron at $25 \mathrm{~g} \mathrm{ha}^{-1}+$ metsulfuron methyl at $4 \mathrm{~g} \mathrm{ha}^{-1}$ and clodinafop at $60 \mathrm{~g} \mathrm{ha}^{-1}+$ carfentrazone ethyl at $20 \mathrm{~g} \mathrm{ha}^{-1}$ significantly reduced the dry weight of weeds than the weedy check and all single application of herbicides in both years. Among weed control treatments, weed-free treatments had WCE (100\%). Among herbicidal treatments sulfosulfuron at $25 \mathrm{~g}$ ha $1+$ metsulfuron methyl at $4 \mathrm{~g} \mathrm{ha}^{-1}$ and clodinafop at $60 \mathrm{~g} \mathrm{ha}^{-1}+$ carfentrazone ethyl at $20 \mathrm{~g} \mathrm{ha}^{-1}$ gave higher WCE compared to other weed control practices in both the. Among the single application of herbicides, carfentrazone ethyl at $20 \mathrm{~g} \mathrm{ha}^{-1}$ recorded higher weed control efficiency at 60 DAS than other single application of herbicides.

The year-wise plant growth parameters like height, number of tillers and dry weight were significantly different due to tillage and weed management practices at 60 DAS (Table 2). In general the growth parameters were higher in ZT plots than CT plots at 60 DAS. Weedy check treatment was significantly lower than the remaining weed control treatments in respect to plant height, number of tillers and dry weight. At 60 DAS weed free treatment led to higher growth parameters. Among the herbicides sulfosulfuron at $25 \mathrm{~g} \mathrm{ha}^{-1}+$ metsulfuron methyl methyl at $4 \mathrm{~g} \mathrm{ha}^{-1}$ led to plant growth parameters compared to isoproturon at $1.0 \mathrm{~kg} \mathrm{ha}^{-1}$ and metsulfuron methyl at $4 \mathrm{~g} \mathrm{ha}^{-1}$ and clodinafop at $60 \mathrm{~g} \mathrm{ha}^{-1}$.

The grain and straw yield of wheat was higher in 2014-15 than in 2013-14. Data on wheat grain and straw yield of both years were significantly influenced by tillage and weed management practices (Table 3). Wheat yields were significantly higher in ZT than $\mathrm{CT}$ in both the years. Weedy check treatment significantly reduced the grain yield of wheat over all the weed control practices. Weed free treatment gave significantly higher wheat grain yield than rest of the treatments. Among the herbicidal treatments, sulfosulfuron at 25 $\mathrm{g} \mathrm{ha}^{-1}+$ metsulfuron methyl at $4 \mathrm{~g} \mathrm{ha}^{-1}$ and clodinafop at $60 \mathrm{~g} \mathrm{ha}^{-1}+$ carfentrazone ethyl at $20 \mathrm{~g} \mathrm{ha}^{-1}$ being at par with each other caused significantly higher grain yield over rest of the weed control practices. The B:C ratio was also higher $\mathrm{ZT}$ than $\mathrm{CT}$ treatments in both the years. The B: $\mathrm{C}$ ratio was higher with, sulfosulfuron at $25 \mathrm{~g} \mathrm{ha}^{-1}+$ metsulfuron methyl at $4 \mathrm{~g} \mathrm{ha}^{-1}$ which was significantly higher than UWC.

The weed flora of the experimental site comprised of Anagallis arvensis L., Melilotus indica L., Chenopodium album L., Convolvulus arvensis L., Melilotus alba L., Vicia sativa L. and Spergulla arvensis L. among broad-leaved, Phalaris minor Retz., Avena ludoviciana among grasses, and, Cyperus rotundus among sedge. Similar weeds flora distribution in wheat has been reported by Nath et al., (2015) and Susha et al., (2014). Among the broad-leaved weeds in wheat Chenopodium album and Melilotus indica was predominant whereas in among grasses Phalaris minor was predominant in wheat. The dynamics of weeds differs under CT and conservation tillage. The weed population under ZT was less than the $\mathrm{CT}$ as because ZT minimizes soil disturbance, which led to poor condition for weed emergence (Marginet et al., 2000). This effect of zerotillage was also compounded by the residue retention on soil surface which suppressed the weed growth due to shedding of residue. This result of Rahman et al., (2000) corroborates our findings. In ZT systems, due to the changes in the temperature and light 
incidence on the soil surface influence dormancy of some weed species. The weed suppressive effects of residue have resulted in greater reduction of weeds in ZT with residue.

Table.1 Effect of different sowing methods and herbicides on weed growth at 60 DAS

Treatment

\begin{tabular}{cccccc}
\hline \multicolumn{2}{c}{$\begin{array}{c}\text { Weed density } \\
\left(\text { No. }^{-2}\right)\end{array}$} & \multicolumn{2}{c}{ Weed dry } & \multicolumn{2}{c}{ WCE $(\%)$} \\
\hline $2013-$ & $2014-15$ & $2013-$ & $2014-$ & $2013-$ & $2014-15$ \\
14 & & 14 & 15 & 14 & \\
\hline & & & & & \\
35.11 & 35.04 & 11.11 & 10.57 & 46.42 & 46.39 \\
42.51 & 41.25 & 12.30 & 12.02 & 46.01 & 45.97 \\
2.98 & 1.91 & 0.82 & 0.88 & 0.94 & 0.73 \\
& & & & & \\
161.6 & 168.0 & 54.39 & 53.56 & 42.50 & 42.47 \\
0.00 & 0.00 & 0.00 & 0.00 & 51.33 & 51.30 \\
45.38 & 47.83 & 11.83 & 11.27 & 44.67 & 45.03 \\
56.81 & 54.33 & 13.45 & 12.84 & 43.45 & 43.54 \\
47.08 & 46.83 & 11.06 & 10.53 & 45.85 & 46.33 \\
40.28 & 38.13 & 11.18 & 10.71 & 44.66 & 44.79 \\
27.66 & 27.83 & 8.09 & 7.68 & 46.57 & 46.92 \\
13.29 & 11.33 & 5.58 & 5.44 & 48.13 & 48.46 \\
23.80 & 21.49 & 8.04 & 7.55 & 46.32 & 45.38 \\
29.31 & 27.08 & 9.02 & 8.52 & 44.49 & 44.64 \\
31.95 & 29.83 & 8.47 & 8.12 & 46.19 & 45.77 \\
9.26 & 7.66 & 4.82 & 4.44 & 49.68 & 48.47 \\
18.08 & 15.58 & 6.21 & 6.15 & 47.02 & 47.30 \\
7.60 & 4.87 & 2.08 & 2.25 & 2.40 & 1.86 \\
\hline
\end{tabular}

Table.2 Effect of different sowing methods and herbicides on wheat growth at 60 DAS

Treatment

\begin{tabular}{cccccc}
\hline \multicolumn{2}{c}{ Plant height $(\mathrm{cm})$} & \multicolumn{2}{c}{$\begin{array}{c}\text { Number of tiller } \\
\mathrm{m}^{-1}\end{array}$} & \multicolumn{2}{c}{ Dry weight (g plant } \\
\hline
\end{tabular}


Table.3 Effect of different sowing methods and herbicides on yield and economics of wheat

\begin{tabular}{|c|c|c|c|c|c|c|}
\hline \multirow[t]{2}{*}{ Treatment } & \multicolumn{2}{|c|}{$\begin{array}{l}\text { Grain yield } \\
\left(\mathrm{q} \mathrm{ha} \mathrm{ha}^{-1}\right)\end{array}$} & \multicolumn{2}{|c|}{$\begin{array}{l}\text { Straw yield } \\
(\mathrm{q} \mathrm{ha-1})\end{array}$} & \multicolumn{2}{|c|}{ B: $\mathrm{C}$ ratio } \\
\hline & $\begin{array}{c}2013- \\
14\end{array}$ & $2014-15$ & $\begin{array}{c}2013- \\
14\end{array}$ & $\begin{array}{c}2014- \\
15\end{array}$ & $\begin{array}{c}2013- \\
14\end{array}$ & $\begin{array}{c}2014- \\
15\end{array}$ \\
\hline \multicolumn{7}{|l|}{ Sowing methods } \\
\hline Zero tillage & 36.54 & 36.71 & 54.50 & 55.09 & 1.70 & 1.68 \\
\hline Conventional tillage & 32.42 & 33.12 & 47.79 & 48.44 & 1.18 & 1.17 \\
\hline $\mathrm{CD}(\mathrm{P}=0.05)$ & 0.33 & 0.09 & 0.87 & 0.21 & & \\
\hline \multicolumn{7}{|l|}{ Weed management } \\
\hline Weedy check & 28.06 & 27.85 & 42.07 & 41.78 & 1.21 & 1.16 \\
\hline Weed free & 38.86 & 43.23 & 57.27 & 57.81 & 0.58 & 0.72 \\
\hline $2,4-\mathrm{D} \mathrm{Na}$ salt $0.5 \mathrm{~kg} \mathrm{ha}^{-1}$ & 33.34 & 33.00 & 49.17 & 49.49 & 1.53 & 1.45 \\
\hline Isoproturon $1.0 \mathrm{~kg} \mathrm{ha}^{-1}$ & 32.68 & 32.93 & 49.08 & 48.88 & 1.44 & 1.43 \\
\hline 2,4 - D Na salt $0.5 \mathrm{~kg} \mathrm{ha}^{-1}+$ Isoproturon $1.0 \mathrm{~kg} \mathrm{ha}^{-1}$ & 32.93 & 33.13 & 49.34 & 49.69 & 1.42 & 1.42 \\
\hline Clodinafop-propargyl $60 \mathrm{~g} \mathrm{ha}^{-1}$ & 33.12 & 33.33 & 49.68 & 49.99 & 1.47 & 1.46 \\
\hline Carfentrazone ethyl $20 \mathrm{~g} \mathrm{ha}^{-1}$ & 34.73 & 34.93 & 52.09 & 51.97 & 1.59 & 1.58 \\
\hline $\begin{array}{l}\text { Clodinafop-propargyl } 60 \mathrm{~g} \mathrm{ha}^{-1}+\text { carfentrazone ethyl } 20 \mathrm{~g} \\
\mathrm{ha}^{-1}\end{array}$ & 37.20 & 38.08 & 55.06 & 57.22 & 1.65 & 1.58 \\
\hline $\begin{array}{l}\text { Clodinafop-propargyl } 50 \mathrm{~g} \mathrm{ha}^{-1}+\text { carfentrazone ethyl } 20 \mathrm{~g} \\
\mathrm{ha}^{-1}\end{array}$ & 35.05 & 35.26 & 52.57 & 52.91 & 1.47 & 1.47 \\
\hline Sulfosulfuron $25 \mathrm{~g} \mathrm{ha}^{-1}$ & 33.89 & 34.10 & 50.86 & 51.14 & 1.42 & 1.50 \\
\hline Metsulfuron methyl $4 \mathrm{~g} \mathrm{ha}^{-1}$ & 34.87 & 33.95 & 47.90 & 50.92 & 1.57 & 1.53 \\
\hline Sulfosulfuron $25 \mathrm{~g} \mathrm{ha}^{-1}+$ metsulfuron methyl $4 \mathrm{~g} \mathrm{ha}^{-1}$ & 37.90 & 38.28 & 56.45 & 57.42 & 1.78 & 1.78 \\
\hline Sulfosulfuron at $25 \mathrm{~g} \mathrm{ha}^{-1}+$ metsulfuron methyl $3 \mathrm{~g} \mathrm{ha}^{-1}$ & 35.62 & 35.82 & 53.33 & 53.73 & 1.61 & 1.60 \\
\hline $\mathrm{CD}(\mathrm{P}=0.05)$ & 0.83 & 0.23 & 2.21 & 0.53 & & \\
\hline
\end{tabular}

The ZTwith residue retention reduces the weed population in wheat because of residue laden condition can suppress weed seedling emergence, delay the time of emergence, and allow the crop to gain an advantage over weeds that ultimately reduce the need for control of weeds. Therefore, retention of crop residue on the soil surface under zero-till systems will be an important multi-tactic approach to manage weed population dynamics in crop rotations.

Weed control treatments were found to reduce the weed density than unweeded control. The lowest weed density recorded under sulfosulfuron at $25 \mathrm{~g} \mathrm{ha}^{-1}+$ metsulfuron methyl at $4 \mathrm{~g} \mathrm{ha}^{-1}$ and clodinafop at $60 \mathrm{~g} \mathrm{ha}^{-1}$ + carfentrazone ethyl at $20 \mathrm{~g} \mathrm{ha}^{-1}$ as postemergence in both the years. This might be due to the broad-spectrum activity and persistence nature of both the herbicides in wheat. In ZT wheat, no ploughing and slightly higher soil moisture may invite early weed germination than conventional-till wheat. Application of sulfosulfuron and metsulfuron methyl controlled the weeds effectively as a broad-spectrum herbicide. The clodinafop and carfentrazone ethyl also controlled narrowleaved and broad-leaved weeds in a single application. The results are in conformity with Punia et al., (2011). Better weed control by application of sulfosulfuron at $25 \mathrm{~g} \mathrm{ha}^{-1}+$ metsulfuron methyl at $4 \mathrm{~g} \mathrm{ha}^{-1}$ clodinafop at $60 \mathrm{~g} \mathrm{ha}^{-1}+$ carfentrazone ethyl at $20 \mathrm{~g} \mathrm{ha}^{-1}$ led to the higher WCE. Weed control treatments were found to reduce the weed density. The lowest weed density recorded weed free followed by sulfosulfuron at $25 \mathrm{~g} \mathrm{ha}^{-1}+$ metsulfuron methyl at $4 \mathrm{~g} \mathrm{ha}^{-1}$ and clodinafop at $60 \mathrm{~g} \mathrm{ha}^{-1}+$ carfentrazone ethyl at $20 \mathrm{~g} \mathrm{ha}^{-1}$ at 30 days and 60 days stages which may also be responsible for increased number of panicles $\mathrm{m}^{-2}$ and shoot number $\mathrm{m}^{-2}$ (De Dutta, 1981). The highest total weed density in weedy check was observed at all the crop growth stages. Among the chemical 
treatments sulfosulfuron at $25 \mathrm{~g} \mathrm{ha}^{-1}+$ metsulfuron methyl at $4 \mathrm{~g} \mathrm{ha}^{-1}$ and clodinafop at $60 \mathrm{~g} \mathrm{ha}^{-1}+$ carfentrazone ethyl at $20 \mathrm{~g} \mathrm{ha}^{-1}$ significantly reduced total weed density and weed dry matter at all the stages of crop growth. The observation made by Pal et al., (2009) support the findings of the present investigation. The highest WCE (100\%) was observed in weed free plots. None of herbicide could turn up statistically superior to sulfosulfuron at $25 \mathrm{~g} \mathrm{ha}^{-1}+$ metsulfuron methyl at $4 \mathrm{~g} \mathrm{ha}^{-1}$ and clodinafop at $60 \mathrm{~g} \mathrm{ha}^{-1}$ + carfentrazone ethyl at $20 \mathrm{~g} \mathrm{ha}^{-1}$. The crop performance varied due to weather conditions particularly rainfall and temperature, during growth period. All the growth parameters were higher in ZT wheat, particularly dry matter accumulation. It can be ascribed to better translocation of photosynthates at vegetative stage of crop due to higher soil moisture and higher soil temperature in cool season month by surface residue retention. Lower plant population and leaf area intercepted less light, which consequently led to lower dry matter accumulation in conventional till wheat. Similar results were also reported by Punia et al., (2011). However, ZT with residue retention improved soil physical, chemical and biological properties more significantly than conventional tillage with residue incorporation that was ultimately led to better crop growth phenology and development in wheat under zero tillage. The plant height, number of branches, dry matter accumulation was also higher with ZT compared to conventional tillage. This might be due to residue application moderated abiotic stress, particularly soil temperature and conserved soil moisture, thus resulting in better crop growth. Zero tillage with residue retention harboured the large number of micro, macro flora and fauna as residue provides the organic foods to earthworms and they controlled soil physical, chemical and physicchemical properties of soil. Weeds always compete with crops for same resources e.g. nutrients, water, space, light and $\mathrm{CO}_{2}$. The overall effect of crop and weed competition is the reduction in the plant growth parameters like, number of tillers, biomass. In weedy situation, very low growth of wheat was recorded in both the years as weeds suppressed the crop growth (Singh, 2000). The effect of weed competition is more prominent unweeded control. As the negative effect of weed competition was significantly reduced by application of sulfosulfuron at 25 $\mathrm{g} \mathrm{ha}^{-1}+$ metsulfuron methyl at $4 \mathrm{~g} \mathrm{ha}^{-1}$ and clodinafop at $60 \mathrm{~g} \mathrm{ha}^{-1}+$ carfentrazone ethyl at $20 \mathrm{~g} \mathrm{ha}^{-1}$ substantially improved the crop growth parameters in both the years (Saha et al., 2010).

Wheat yield was significantly by tillage and weed management practices. All the productivity parameters wheat (grain, and straw) were higher on ZT than CT conditions. The grain yield in ZT was significantly higher due to greater number of ear bearing tillers, wheat grains ear ${ }^{-1}$, and 1000-grain weight resulting in higher grain yield. This might have resulted from greater sink and good growth in reproductive phase. Also there may be a positive impact of ZT and residue on soil water balance because of reduction in soil evaporation and better soil water retention that ultimately increased wheat yields. The findings of Halvorson et al., (2002) corroborate our result. The highest gross returns and net returns were in zero tillage treatments because of more yield and less cost of cultivation however benefit: cost ratios (B: $\mathrm{C}$ ratio) was maximum in without residue treatments. This is due to the cost of residue was added in with residue treatments that ultimately reduced the cost of cultivation in ZT. In the weed-free check, hand weeding was done during cropping season to keep the fields free of weeds. This incurred higher cost of cultivation compared to that in ready-mix and sequential application of herbicides. As a 
result weed-free check was inferior to the most promising herbicide treatment i.e., sulfosulfuron at $25 \mathrm{~g} \mathrm{ha}^{-1}+$ metsulfuron methyl at $4 \mathrm{~g} \mathrm{ha}^{-1}$. In terms of economics, application of sulfosulfuron at $25 \mathrm{~g} \mathrm{ha}^{-1}+$ metsulfuron methyl at $4 \mathrm{~g} \mathrm{ha}^{-1}$ gave higher net returns, gross returns because more price incurred from yield. Overall, the combine use of ZT+ sulfosulfuron at $25 \mathrm{~g} \mathrm{ha}^{-1}+$ metsulfuron methyl at $4 \mathrm{~g} \mathrm{ha}^{-1}$ ha proved better in terms system economics. Therefore, this combination of $\mathrm{ZT}+$ sulfosulfuron at 25 $\mathrm{g} \mathrm{ha}^{-1}+$ metsulfuron methyl at $4 \mathrm{~g} \mathrm{ha}^{-1}$ resulted in significantly higher productivity of wheat and net returns in. On the basis of present study, it is concluded that sulfosulfuron at $25 \mathrm{~g} \mathrm{ha}^{-1}+$ metsulfuron methyl at $4 \mathrm{~g} \mathrm{ha}^{-1}$ and clodinafop at $60 \mathrm{~g} \mathrm{ha}^{-1}$ + carfentrazone ethyl at $20 \mathrm{~g} \mathrm{ha}^{-1}$ can be used for effective weed control in wheat for broadspectrum control of weeds and also for higher productivity and profitability.

\section{References}

Brainard, D.C., Haramoto, E., Williams, II. and Mirky, M.M.S. 2013. Towards a no - till no - spray future. Introduction to a symposium on non-chemical weed management for reduced tillage cropping systems. Weed Technology 27(1): 190-192.

De Dutta, S.K. 1981. Principles of rice production. A Wily International Science Publication.

Gomez, K.A. and Gomez, A.A. 1984. Statistical Procedures for Agricultural Research. John Wiley and Sons, New York.G.

Halvorson, A.D., Wienhold, B.J. and Black, A.L. 2002. Tillage, nitrogen and cropping system effects on soil carbon sequestration. Soil Science of Society of America Journal. 66: 906-912.

Marginet, A., Van Acker, R., Derksen, D.A., Entz, M.H. and Andrews, T. 2000. Wild oat (Avena fatua) emergence as affected by tillage and eco-district. In: Proc. of the National Meeting - Expert Committee on Weeds. Alberta, Canada, pp. 31-39.

Morris, N.L., Miller, P.C.H., Orson, J.H. and Froud-Willams, R.J. 2010. The adoption of non-inversion tillage system in the United Kingdom and the agronomic impact on soil, crops and the environment. A review. Soil and Tillage Research. 110(1-2): 1-15.

Nath, C.P., Das, T.K., Rana, K.S., Pathak, H., Bhattacharyya, R., Paul, S., Singh, S.B., and Meena, M.C. 2015. Weedmanagement and wheat productivity in a conservation agriculture- based maize (Zea mays)-wheat (Triticum aestivum)mungbean (Vigna radiata) system in north-western Indo-Gangetic plains of India. Indian Journal of Agronomy. 60 (4): 554-563.

Pal, S., Banerjee, H. and Mandal, N.N. 2009. Efficacy of low dose herbicides against weeds in transplanted kharif rice. The Journal of Plant Protection Sciences. 1 (1): 31-33.

Punia, S.S., Singh, S. and Yadav, D. 2011. Bioefficacy of imazethapyr and chlorimuron-ethyl in clusterbean and their residual effect on succeeding rabi crops. Indian Journal of Weed Science. $43(1 / 2): 48-53$.

Rahman, A., James, T.K., Mellsop, J. and Grbavac, N. 2000. Effect of cultivation methods on weed seed distribution and seedling emergence. In: Proc. of the 53rd New Zealand Plant Prot. Conference, pp. 28-33.

Rao, A.N., Johnson, D.E., Sivaprasad, B., Ladha, J.K. and Mortimer, A.M. 2007. Weed management in direct seeded rice. Advances in Agronomy. 93: 153-255.

Saha, S., Chakraborty, D., Sharma, A.R., Tomar, R.K., Bhadraray, S., Sen, U., Behera, U.K., Purakayastha, T.J., Garg, 
R.N and Kalra, N. 2010. Effect of tillage and residue management on soil physical properties and crop productivity in maize (Zea mays) Indian mustard (Brassica juncea) system. Indian Journal of Agricultural Sciences. 80 (8): 679 - 685.

Singh, G. and Singh, V.P. 2005a. Compatibility of clodinafop-propargyl and fenoxaprop-p-ethyl with carfentrazone- ethyl, metsulfuronmethyl and 2, 4-D. Indian Journal of Weed Science. 37: 1-5.

Singh, G., Singh, M. and Singh V.P. 2002. Effect of metsulfuron-methyl alone and in combination with 2, 4-D and surfactant on non-grassy weeds and wheat yield. Indian Journal of Weed Science. 34: 175-177.

Singh, G. and Singh, V. P. 2005. Compatibility of clodinafop - propargyl and fenoxaprop - p - ethyl with carfentrazone ethyl, metsulfuron methyl and 2, 4 - D. Indian Journal of Weed Science. 37 (1\&2): 1-5.

Singh, M. 2000. Studies on seed rate requirement and time of first irrigation in no till wheat following rice. M.Sc.

Dissertation. Punjab Agricultural University, Ludhiana, India.

Singh, S.S., Malik, R.K, Gupta, R. and Singh, S. 2005b. Weeds problems Associatd with the New Technology in Rice Wheat Cropping System of Bihar. Accleration the adoption of RCT in $R-$ $W$ system of the Indo-Gangetic plains. Pp 252.

Susha, V.S., Das, T.K., Sharma, A.R. and Nath, C.P. 2014. Carry-over effect of tank-mix and sequential applications of herbicides supplemented with zero and conventional tillage on weed competition, yield and economics in wheat. Indian Journal of Agronomy. 59 (1): 41-47.

Yadav, D.B., Yadav, A., Singh, S. and Lal, Roshan, R. 2009. Compatibility of fenoxaprop-p-ethyl with carfentrazoneethyl metsulfuron-methyl and 2, 4-D for controlling complex weeds of wheat. Indian Journal of Weed Science. 41 (3/4): 157-160.

\section{How to cite this article:}

Pramod Kumar Singh, Pradeep Prasad, Manita Kumari and Rajiv Nayan. 2017. Tillage and Post-Emergence Herbicides Effect on Weed Growth and Productivity of Wheat (Triticum Aestivum L.). Int.J.Curr.Microbiol.App.Sci. 6(7): 1656-1664. doi: https://doi.org/10.20546/ijcmas.2017.607.200 